\title{
INNOVATIVE EHEALTH INTERVENTIONS IN NURSING RESEARCH. HOW TO UTILIZE A MIXED METHOD APPROACH TO DESIGN, DEVELOPMENT, EVALUATION AND IMPLEMENTATION
}

\author{
INTERVENCIONES INNOVADORAS DE ESALUD EN LA \\ INVESTIGACIÓN DE ENFERMERÍA. CÓMO UTILIZAR UN ENFOQUE \\ DE MÉTODO MIXTO PARA EL DISEÑO, DESARROLLO, EVALUACIÓN \\ E IMPLEMENTACIÓN
}

\author{
INTERVENÇÓES INOVADORAS DE ESAÚDE NA PESQUISA EM \\ ENFERMAGEM. COMO USAR UM MÉTODO MIXTO PARA O \\ DESENHO, DESENVOLVIMENTO, AVALIAÇÃO E IMPLEMENTAÇÃO
}

\author{
ELIN BørøSUnD* \\ Cecilie Varsi**
}

\begin{abstract}
Electronic health (eHealth) interventions have shown promising results in optimizing self-management and care for patients. eHealth offers a large range of solutions to be used by the patient, nurses and other health professionals when providing care and follow-up for patients, families, and communities. Nurses, as the largest group of health care providers, have a responsibility in the development, research and implementation of eHealth interventions. The aim of this article is to describe methods, frameworks and models for development and testing of eHealth interventions, including security and privacy considerations and methods for implementation into the health care service. To succeed with development, testing and implementation of eHealth interventions, the following steps could be addressed: 1) base the intervention on existing evidence when available, 2) include all relevant stakeholders in the development phase, 3) develop a business model at project start and plan for implementation, 4) establish usability, acceptability, compliance, and delivery of the intervention through a feasibility pilot prior to larger studies, 5) test for intervention effect by using an appropriate study design and perform process- and economic evaluation to supplement findings, and 6) use appropriate implementation strategies to implement efficient interventions and evaluate the implementation.
\end{abstract}

Key words: eHealth; Intervention development; Implementation; Nursing Research; Methods.

\footnotetext{
*Registered Nurse, PhD. Center for Shared Decision Making and Collaborative Care Research, Division of Medicine, Oslo University Hospital, Oslo, Norway. Email: Elin.Borosund@rr-research.no. Corresponding author.

**Registered Nurse, PhD. Center for Shared Decision Making and Collaborative Care Research, Division of Medicine, Oslo University Hospital, Oslo, Norway. Email: Cecilie.Varsi@rr-research.no
} 


\section{RESUMEN}

Las intervenciones de salud electrónica (eSalud o eHealth) han mostrado resultados prometedores en la optimización de la autogestión y el cuidado de los pacientes. La eSalud ofrece una amplia variedad de soluciones para ser utilizadas por el paciente, enfermeros y enfermeras; y otros profesionales de la salud a la hora de proporcionar atención y seguimiento a los pacientes, las familias y las comunidades. Los enfermeros y las enfermeras, como el grupo más numeroso de proveedores de atención de salud, son responsables del desarrollo, la investigación y la aplicación de las intervenciones en materia de salud electrónica. El objetivo de este artículo es describir los métodos, marcos de referencia y modelos para desarrollar y probar las intervenciones de salud electrónica, incluyendo las consideraciones de seguridad y privacidad y los métodos para su aplicación en la atención de salud. Para tener éxito en el desarrollo, prueba e implementación de las intervenciones de e-Salud se podrían considerar los siguientes pasos: 1) basar la intervención en la evidencia existente cuando esté disponible, 2) incluir a todas las partes interesadas en la fase de desarrollo, 3) desarrollar un modelo de negocio al inicio del proyecto y planificar la implementación, 4) establecer la usabilidad, aceptabilidad, cumplimiento y entrega de la intervención a través de una prueba piloto de factibilidad antes de realizar estudios de mayor alcance, 5) probar el efecto de la intervención mediante el uso de un diseño de estudio apropiado y llevar a cabo una evaluación económica y de proceso para complementar los hallazgos y 6) utilizar estrategias de implementación adecuadas para implementar intervenciones eficientes y evaluar la implementación.

Palabras clave: eSalud; Desarrollo de intervención; Implementación; Investigación en Enfermería; Métodos.

\section{RESUMO}

As intervenções de saúde eletrônica (eSaúde ou eHealth) mostraram resultados promissores na optimização do autogerenciamento e do cuidado aos pacientes. A eSaúde oferece uma amplia variedade de soluçóes a serem usados pelo paciente, enfermeiros e enfermeiras; e outros profissionais da saúde na prestação de cuidados e acompanhamento a pacientes, famílias e comunidades. Os enfermeiros e as enfermeiras, como o maior grupo de prestadores da atenção de saúde, são responsáveis do desenvolvimento, pesquisa e aplicação das intervençôes eletrônicas em saúde. O objetivo deste artigo é descrever os métodos, quadros de referência e modelos para o desenvolvimento e teste das intervençóes eletrônicas de saúde, incluindo as consideraçóes de segurança e privacidade e métodos para sua aplicação na atençáo da saúde. Para ter sucesso no desenvolvimento, teste e implementação das intervençóes do eSaúde, as seguintes etapas podem ser consideradas: 1) basear a intervenção na evidência existente, quando estiver disponível, 2) incluir todas as partes interessadas na fase de desenvolvimento, 3) desenvolver um modelo de negócios no início do projeto e planejar a implementação, 4) estabelecer a usabilidade, aceitabilidade, conformidade e entrega da intervenção através de um teste piloto de factibilidade antes de realizar estudos maiores, 5) testar o efeito da intervenção através do uso de um desenho apropriado e realizar uma avaliação econômica e de processo para complementar as descobertas e 6) utilizar estratégias de implementação apropriadas para a implementação de intervençóes eficientes e avaliar a implementação.

Palavras-chave: eSaúde; Desenvolvimento de intervenção; Implementação; Pesquisa em Enfermagem; Métodos.

Fecha recepción: 02/12/2019

Fecha aceptación: 18/12/2019

\section{INTRODUCTION}

Electronic health (eHealth) interventions, defined as "health services and information delivered or enhanced through the internet and related technologies"(1), have shown promising results in providing patients with self-management support ${ }^{(2)}$, symptom management ${ }^{(3)}$, enabling online patientprovider communication, monitoring and shared decision making ${ }^{(4)}$. eHealth interventions have the potential to optimize health-related processes, reach a large number of people and achieve cost effectiveness ${ }^{(5)}$. This holds promise as an ageing population worldwide and an increased 
prevalence and burden of lifestyle and chronic diseases, including cancer, challenges the health care systems due to increased pressure and costs. The World Health Organization (WHO) strongly recommends utilization of eHealth interventions ${ }^{(6)}$. Nurses, as the largest group of health care providers, have a particular responsibility in the development, implementation and research on eHealth interventions ${ }^{(7)}$. Nurses hold a wide variety of roles and are involved in many different contexts of the health care system ${ }^{(8)}$. Their core tasks include offering care for patients and their families. As well as providing care and follow up around the clock they have a central role in care coordination. To better realize the full potential of nursing, it seems vitally important that nurses have knowledge, access, premises for and are active users of eHealth.

The aim of this article is to describe methods, frameworks and models for development and testing of eHealth interventions, including security and privacy considerations and methods for implementation into the health care service.

\section{eHealth interventions are Complex interventions:} The Medical Research Council in the United Kingdom (UK) has built, updated and published guidelines for developing and evaluating complex interventions ${ }^{(9,10)}$. The guidelines are widely used all over the world, helping health care providers and researchers to utilize appropriate methods. To be classified as a complex intervention, the intervention must be considered according to the following elements ${ }^{(9)}$ :

- Number of interacting components

- Number and difficulty of behaviors required by those delivering the intervention

- Number of groups and organizational levels targeted by the intervention

- Number and variability of outcomes

- Degree of flexibility or tailoring of the intervention permitted

eHealth interventions can be classified as complex interventions as they often address most of these elements. To develop and evaluate complex interventions, including eHealth interventions, the following areas are important $t^{(9)}$ : 1) A good theoretical understanding is needed regarding how the intervention causes change, so that weak links in the causal chain can be identified and strengthened. 2) Lack of evidence when testing the intervention may reflect implementation failure rather than genuine ineffectiveness. A thorough process evaluation is therefore needed to identify implementation problems. 3) A single primary outcome may not make best use of the data. A range of measures will be needed and unintended consequences picked up where possible. 4) Ensuring strict standardization may be inappropriate. The intervention may work better if a specified degree or adaptation to local settings is allowed for in the protocol.

Furthermore, the newly developed framework "the non-adoption, abandonment, scale-up, spread and sustainability (NASSS) framework", also points to the notion that technology projects are complex ${ }^{(11)}$. To succeed with technology projects, it is therefore necessary to understand where the complexity lies and reduce and adapt the complexities as much as possible. The NASSS framework considers seven domains: 1) The illness or condition, 2) The technology, 3) The value proposition (efficacy, safety and cost-effectiveness), 4) The intended adopters (staff and patients/clients and their caregivers), 5) The organization(s), 6) The wider system, and 7) Evolution over time. By taking into account these domains in the development, testing and implementation of complex eHealth interventions, the NASSS framework can act as a helpful tool when seeking to improve the success of technology projects ${ }^{(11)}$.

\section{Design and development of eHealth} interventions: To utilize the full potential, eHealth interventions must be evidence-based and available to the intended users. A WHO guideline of Digital Health stated ${ }^{(12)}$ : "A key challenge is to ensure that all people enjoy the benefits of digital technologies for everyone. We must make sure that innovation and technology helps to reduce the inequities in our world, instead of becoming another reason people are left behind. Countries must be guided by evidence to establish sustainable harmonized digital systems, not seduced by every new gadget." A range of frameworks can guide design and development of eHealth behavioural change interventions. A recent systematic review states that all available frameworks underline the importance of user involvement in the developing phase of the interventions ${ }^{(13)}$. 
There are several resources available to guide involvement of users (including patients, caregivers, health care providers and organizations representatives), in research ${ }^{(14,15)}$. Involvement of users is connected to their feeling of being empowered and valued, gaining confidence and life skills ${ }^{(16)}$. By involving them, researchers develop a greater understanding and insight into their research area, gaining respect and a good rapport with the community ${ }^{(16)}$.

To increase motivation and adherence to eHealth interventions, the end users need to be part of the design and development process to ensure that interventions are user friendly and useful when delivered in an electronic format ${ }^{(17)}$. It is also important to adapt the intervention to health care providers' work flow and the organization of intended use. As examples, when health care researchers and a software team developed appbased programs for stress management in cancer and chronic pain self-management, patients, health care providers, eHealth experts, and the hospital privacy and security department were involved in the development process ${ }^{(18,19)}$. The Center for eHealth Research and Disease Management comprehensive roadmap (CEHRES ROADMAP) ${ }^{(20)}$ was used to guide the development process as it recommends a multidisciplinary approach and a continuous systematic evaluation throughout the development process. Also elements from the fields of User centered design $^{(21)}$ and Service design ${ }^{(22)}$ were used, as both fields acknowledge the end user perspectives, the context of users and provide practical tools and methods for user involvement, such as interviews, workshops, paper prototyping and usability testing.

Privacy and security: To ensure that patient information is kept safe and available, security and privacy elements must be built into the eHealth interventions. In 2018, the MEASURE Evaluation released the "mHealth Data Security, Privacy, and Confidentiality: Guidelines for program implementers and policymakers"(23), and a "Companion Checklist"(24). These documents can be of help when planning security and privacy in eHealth interventions. Security encompasses physical, technological, or administrative safeguards or tools used to protect identifiable health data from unwarranted access or disclosure ${ }^{(25)}$. It is the technology infrastructure that protects sensitive information. Privacy is a basic human right and includes "an individual's right to control acquisition, uses, or disclosures of his or her identifiable health data" $^{(26)}$, that is any information that the person wants to keep private. Confidentiality is the obligation of those who receive information to respect the privacy interests of those to whom the data relates ${ }^{(26)}$, and is a mechanism for protecting privacy. Development of eHealth interventions that addresses security, privacy and confidentiality issues can contribute to increased trust among users and thereby to increased use of the intervention ${ }^{(17)}$.

\section{METHODS FOR EVALUATION}

Feasibility pilots: After developing an eHealth intervention it is important to address usability, acceptability, compliance, delivery of the intervention, recruitment and retention prior to an experimental study. These issues can be addressed in a mixed method feasibility study ${ }^{(10,27,28)}$. After development of the previous mentioned app-based stress management program for cancer patients, the intervention was tested in a mixed method feasibility pilot prior to a larger randomized controlled trial $(\mathrm{RCT})^{(29)}$. In this study, system use, usefulness, ease of use, project procedures and preliminary effects were explored. A combination of questionnaires, server log-data and interviews were used to collect data. Findings indicated that the intervention had no technical challenges and that it was easy to use. Results also indicated preliminary evidence on efficacy. Participant input was used to make small improvements in the intervention prior to the RCT.

Experimental studies: The complexity of eHealth interventions carry some challenges for evaluation ${ }^{(9)}$. There are many study designs to choose from, and different design suit different studies. If possible, a robust experimental design such as a RCT will be preferred to test the intervention and establish causality (the link between the intervention and the effect). However, this design might not be appropriate due to different circumstances (i.e., large policy changes in the health systems, difficulties for health care providers to not offer the intervention to the control group). In these cases other designs such as cluster randomized design, 
stepped wedge design, quasi experimental design can be used ${ }^{(9,10)}$.

Analysis of user pattern and explorative analysis: In addition to intention-to-treat analysis on effects, it can be important to perform perprotocol analysis exploring whether use of the intervention is connected to effects. In a study of a web-based self-management support program for breast cancer patients, access to secure e-mail gave reduction of depression compared to a control group ${ }^{(30)}$. Explorative analyses showed that use was not connected to effect, and this might indicate that the psychological effect of having access to the intervention was important. In other eHealth interventions, use is strongly connected to effects and it is therefore important to focus on intervention adherence ${ }^{(31)}$.

It is also interesting to explore if there are groups who use the intervention more or less (i.e., do age, gender, education and other demographic variables impact use?). Server log-data can give insight on what part of the intervention is used or not. This knowledge can be used to improve the intervention after the study.

Process evaluation: When seeking new knowledge regarding the eHealth interventions' impact for the users (i.e. patients and health care providers), it is not sufficient to study patient outcomes alone. Also the process and the context where the study took place, needs to be investigated to provide a comprehensive picture over not only if the intervention produced significant results, but also more details regarding who benefited from it and under which circumstances. The UK Medical Research Council has developed a helpful guidance for process evaluation research ${ }^{(32)}$. Process evaluation can be conducted in different ways, depending on the question being asked ${ }^{(10)}$. Some studies monitor intervention delivery, other explore potential mediators of effect and some conduct interviews with patients and health care providers to get a broader insight into results.

Economic evaluation: Understanding the effects of an intervention is of little use if the cost of its benefits compared to alternative approaches, or doing nothing, cannot be determined ${ }^{(10)}$. To establish this knowledge, collaboration with health economists can be of great value, and can help to identify important data to collect on cost and benefits during the study. This information can be important for decision- and policy makers.

\section{IMPLEMENTATION}

Despite promising evidence of positive effects of eHealth interventions for patients and health care providers, their implementation into clinical practice remains challenging. There is no doubt that eHealth interventions and programs are here to stay, but there is a need to include implementation planning already when developing and testing the interventions. The business model for eHealth intervention needs to be developed already from the start. When implementing eHealth interventions into clinical care, use of implementation strategies, such as assessment of barriers and facilitators, training, leader involvement, feedback on progress and internal and external facilitation and support can be useful ${ }^{(33)}$. Finally, implementation outcomes and service outcomes should be investigated, to assess the effectiveness of the implementation, with the same rigor and comprehensiveness as the studies on patient outcomes ${ }^{(34)}$. There are a great number of frameworks for the different phases of implementation, i.e. planning, execution and evaluation. Nilsen's overview article can be useful ${ }^{(35)}$.

\section{Summary}

In summary, to succeed with development, testing and implementation of eHealth interventions, the following steps could be addressed: 1) base the intervention on existing evidence when available, 2) include all relevant stakeholders in the development phase, 3) develop a business model at project start and plan for implementation, 4) establish usability, acceptability, compliance, and delivery of the intervention through a feasibility pilot prior to larger studies, 5) test for intervention effect by using an appropriate study design and perform process-and economic evaluation to supplement the findings, and 6) use appropriate implementation strategies to implement efficient interventions and evaluate the implementation. 


\section{REFERENCES}

1. Eysenbach G. What is e-health? J Med Internet Res. 2001; 3(2): e20.

2. Whitehead L, Seaton P. The Effectiveness of SelfManagement Mobile Phone and Tablet Apps in Long-term Condition Management: A Systematic Review. J Med Internet Res. 2016; 18(5): e97.

3. Fridriksdottir N, Gunnarsdottir $S$, Zoega $S$, Ingadottir B, Hafsteinsdottir EJG. Effects of webbased interventions on cancer patients' symptoms: review of randomized trials. Support Care Cancer. 2018; 26(2): 337- 51.

4. Noar SM, Harrington NG. eHealth applications. Promising strategies for behavior change. New York: Routledge; 2012.336 p.

5. Van Gemert-Pijnen LK, Kelders SM, Kip H, Sanderman R. eHealth research, Theory and Development. New York: Routledge; 2018. 376 p.

6. World Health Organization. Global diffusion of eHealth: Making universal health coverage achievable. Report of the third global survey on eHealth [Internet]. Geneva: WHO; 2016 [cited 2019 Dec 12]. Available from: https://www.who. int/goe/publications/global_diffusion/en/

7. Børøsund E, Varsi C. Intervenciones innovadoras de e-salud en la práctica y la investigación de la enfermería. Cienc. enferm. [Internet]. 2019 [citado 12 Dic 2019]; 25(1). Available from: https://scielo. conicyt.cl/scielo

8. The Lancet. 2020: craig unleashing the full potential of nursing. The Lancet. 2019; 394(10212): 1879.

9. Craig P, Dieppe P, Macintyre S, Michie S, Nazareth I, Petticrew M. Developing and evaluating complex interventions: the new Medical Research Council guidance. BMJ. 2008; 337(7676): a1655.

10. Richards DM, Hallberg IR. Complex interventions in health. An overview of research methods. New York: Routledge; 2015. 382 p.

11. Greenhalgh T, Wherton J, Papoutsi C, Lynch J, Hughes G, A'Court C, et al. Beyond Adoption: A New Framework for Theorizing and Evaluating Nonadoption, Abandonment, and Challenges to the Scale-Up, Spread, and Sustainability of Health and Care Technologies. J Med Internet Res. 2017; 19(11): e367.

12. Word Health Organization. WHO guideline: recommendations on digital interventions for health system strengthening. Geneva: Word Health Organization; 2019. 124 p.

13. Carbonnel F, Ninot G. Identifying Frameworks for Validation and Monitoring of Consensual Behavioral Intervention Technologies: Narrative Review. J Med Internet Res. 2019; 21(10): e13606.

14. INVOLVE. Briefing notes for researchers: involving the public in NHS, public health and social care research [Internet]. Eastleigh: National Institute for Health Research; 2012 [cited 2019 Dec 12] Available from: www.invo.org.uk/resource -centre/ resource-for-researchers/

15. European Patients' Academy [Internet]. Bruselas: European Patients' Academy; 2019 [cited 2019 Dec 12]. Available from: https://www.eupati.eu/

16. Brett J, Staniszewska S, Mockford C, Herron-Marx S, Hughes J, Tysall C, et al. A systematic review of the impact of patient and public involvement on service users, researchers and communities. Patient. 2014;7(4):387-95.

17. Torous J, Nicholas J, Larsen ME, Firth J, Christensen $\mathrm{H}$. Clinical review of user engagement with mental health smartphone apps: evidence, theory and improvements. Evid Based Ment Health. 2018; 21(3): 116-19.

18. Børøsund E, Mirkovic J, Clark MM, Ehlers SL, Andrykowski MA, Bergland A, et al. A Stress Management App Intervention for Cancer Survivors: Design, Development, and Usability Testing. JMIR Formative Res. 2018; 2(2): e19.

19. Ledel Solem IK, Varsi C, Eide H, Kristjansdottir OB, Børøsund E, Schreurs KM, et al. Design and Development of EPIO: A User-centered Approach to an Evidence-based eHealth Pain Management Intervention for People with Chronic Pain. J Med Internet Res. Forthcoming 2020.

20. Van Gemert-Pijnen JE, Nijland N, Van Limburg M, Ossebaard HC, Kelders SM, Eysenbach G, et al. A holistic framework to improve the uptake and impact of eHealth technologies. J Med Internet Res. 2011; 13(4): e111.

21. De Vito Dabbs A, Myers BA, Mc Curry KR, Dunbar-Jacob J, Hawkins RP, Begey A, et al. Usercentered design and interactive health technologies for patients. Comput Inform Nurs. 2009; 27(3): 175-83.

22. Stickdorn M, Schneider J. This is service design thinking: Basics, tools, cases. Amsterdam: BIS Publishers; 2012.

23. Spigel LW, Wambugu S, Villella C. mHealth Data Security, Privacy, and Confidentiality: Guidelines for Program Implementers and Policymakers. Chapel Hill: MEASURE Evaluation; 2018. ISBN: 978-1-64232-003-9

24. Spigel LW, Wambugu S, Villella C. mHealth Data Security, Privacy, and Confidentiality Guidelines: Companion Checklist. Chapel Hill: MEASURE Evaluation; 2018. 38 p.

25. Gejibo SH. Towards a Secure Framework for mHealth. A Case Study in Mobile Data Collection Systems [PhD dissertation on the Internet]. Bergen: University of Bergen; 2015. [cited 2019 
Dec 12]. 184 p. Available from: http://hdl.handle. net/1956/10652

26. Cohn S. Privacy and confidentiallity in the nationwide health information network. National Committee on Vital and Health Statistics [Internet]. Washington; 2006 [cited 2019 Dec 12]. Available from: https://library.ahima.org/doc?oid=75960\#. XeKWMpNKhaQ

27. Polit DF, Beck CH. Nursing research: generating and assessing evidence for nursing practice. 10th. ed. Philadelphia: Wolters Kluwer Health; 2017.784 p.

28. Bowen DJ, Kreuter M, Spring B, Cofta-Woerpel L, Linnan L, Weiner D, et al. How we design feasibility studies. Am J Prev Med. 2009; 36(5): 452-57.

29. Børøsund E, Varsi C, Clark MM, Ehlers SL, Andrykowski MA, Sleveland HRS, et al. Pilot testing an app-based stress management intervention for cancer survivors. Transl Behav Med [Internet]. 2019 [cited 2019 Dec 12]. Available from: https://academic.oup.com/tbm/advancearticle/doi/10.1093/tbm/ibz062/5477435

30. Børøsund E, Cvancarova M, Moore SM, Ekstedt M, Ruland CM. Comparing Effects in Regular Practice of E-Communication and Web-Based Self-Management Support Among Breast Cancer
Patients: Preliminary Results From a Randomized Controlled Trial. J Med Internet Res. 2014; 16(12): e295.

31. Kelders SM, Kok RN, Ossebaard HC, Van GemertPijnen JE. Persuasive system design does matter: a systematic review of adherence to web-based interventions. J Med Internet Res. 2012; 14(6): e152.

32. Moore GF, Audrey S, Barker M, Bond L, Bonell C, Hardeman W, et al. Process evaluation of complex interventions: Medical Research Council guidance. BMJ. 2015; 350: h1258.

33. Varsi C, Solberg Nes L, Kristjansdottir OB, Kelders SM, Stenberg U, Zangi HA, et al. Implementation Strategies to Enhance the Implementation of eHealth Programs for Patients With Chronic Illnesses: Realist Systematic Review. J Med Internet Res. 2019; 21(9): e14255.

34. Proctor E, Silmere H, Raghavan R, Hovmand P, Aarons G, Bunger A, et al. Outcomes for implementation research: conceptual distinctions, measurement challenges, and research agenda. Adm Policy Ment Health. 2011; 38(2): 65-76.

35. Nilsen P. Making sense of implementation theories, models and frameworks. Implement Sci. 2015;10(1): 53 . 